\title{
Anger Metaphors in Seneca's Medea
}

\author{
Katalin Bán \\ (University of Szeged)
}

\begin{abstract}
Seneca's tragedies are characterized by widespread use of metaphors, emotions and personality traits of heroes and heroines often appear in imagery representations. In my study, I intend to examine the central anger metaphors and pictorial representations of Seneca's Medea, that is, the metaphors of various manifestations of the sea storm, the fire and the snake which are represented and in many cases intertwined with each other in the character of the heroine.

Medea is a drama of the anger, the destructive forces in the soul, the revenge, which Seneca often expresses with the use of these pictorial representations and compares them to the destructive forces of nature. These metaphors inspired by nature highlight an important point in Seneca's philosophy: the linkage of the cosmic and the individual. My aim is to highlight Seneca's Stoic interpretation of virtuous life through these metaphors: if we do not live according to Stoic philosophy and in harmony with nature, the balance of the soul might be shaken, and emotions might take control over our rational decision-making ability. In the tragedy Seneca creates subversely a counterworld to the world of Stoic virtue, and metaphors are applied not only to the different manifestations of human nature as direct comparisons, but also to express Stoic ideals. Their various aspects are complex and versatile in Seneca's prose and poetry, thus it is also worth examining his prose works to completely understand their role.
\end{abstract}

\section{Keywords}

anger; Medea; Stoicism; Seneca; metaphors 


\section{Introduction}

Metaphor is essential in the formation of emotions and other psychological concepts in particular. Seneca's tragedies are characterized by a widespread use of metaphors, that is to say, the emotions and personality traits of heroes and heroines that often appear in imagery representations. In my study, I intend to examine the central anger metaphors and the pictorial representations of Seneca's Medea, that is, the various manifestations of the sea storm, the fire and the snake, which are often represented together when depicting the character of the heroine. For Seneca, metaphors inspired by nature are especially important due to his obvious interest in the natural world. The idea of living in harmony with nature is fundamental to understand the larger contexts of Seneca's works. Seneca's metaphors are not used for decorative purposes, but rather for cognitive ones, consciously conveying his Stoic philosophy in relation to human passions. The protagonist places herself in the middle of the world stage and declares that the whole cosmos contributes and becomes involved in her anger and suffering. ${ }^{1}$ My aim is to highlight this dual rhetorical representation, how it sheds light on the author's relationship to Stoic philosophy, and how he interprets these cosmic projections, the interdependence of the physical and the spiritual, of the cosmic and the personal. Recent scholarly literature has dealt with Seneca's pictorial representations in his tragedies, but as far as I know, no investigation has examined all the main anger metaphors of Seneca's Medea in relation to Stoic philosophy as yet. Since these metaphors are present throughout Seneca's literary works, it is also worth examining his prose works to completely understand their role. ${ }^{2}$

\section{Storm metaphor as Medea's anger and uncertainty}

Seneca's originality is reflected in the fact that the presentation of metaphors in the tragedy is also explained in his prose works, thus creating a view of their full meaning in Seneca's thinking, which could not be highlighted in the narrower context of the tragedy genre. Medea is the drama of anger, the destructive forces in the soul and revenge, which Seneca often expresses with the use of these representations and compares them to the destructive forces of nature. Compared to Euripides, Seneca expresses the heroine's

1 Segal (2008: p. 136). According to Stoic philosophy, human beings must live according to their personal nature, with a full understanding of the universe's system and must utilise this knowledge to inform their actions. This can be put down to the fact that Stoic philosophy is: divinorum et humanorum scientiam. (Sen. epist. 89,5). Seneca dramatizes the protagonist's suffering with a wide range of pictorial representations that connect man and nature, and projects the "personal emotion into a cosmic frame." Rosenmeyer (1989: p. 124) claims that the play emphasizes the integration of the human and the cosmic. In this mosaic of sumpatheia and contagio, the ostensible theme of divine punishment is neglected. For more details see e.g. Sen. epist. 90,3; Inwood (2008: pp. 167-168); Setaioli (2007: p. 334).

2 Bartsch argues that Seneca's metaphors are "the most striking aspect of his teaching”. In his opinion there are two basic roles of senecan metaphors: to help us see a correct view of what something 'really' is, and to help us see something as something else ("translation" function). Metaphors are "maps onto theory in a way that enables the listener to grasp an abstract concept via an experience familiar to him or familiar to the world he lives in." Bartsch (2009: p. 213). 
anger in many more cases with these pictorial representations. ${ }^{3}$ Seneca presents the various visual representations of the sea storm in terms of human emotions mainly in De Tranquillitate Animi and De Ira. ${ }^{4}$ In the light of these two works, Seneca uses the rampage of the sea storm to represent Medea's anger, revenge, doubt and uncertainty that appear as the opposite of the ideal Stoic state of mind. ${ }^{5}$ According to Braicovich, ${ }^{6}$ the inner mechanisms of Medea's mind show a clear flexibility of her inner reasoning and these facts clarify her inconstancy, uncertainty and fluctuations. When examining these examples, a thematic trend can be found in Seneca's use of metaphors. The metaphor of the storm does not only represent a single emotional state, but it also has two key aspects: on the one hand, the power of the storm illustrates human wrath, and on the other hand, its chaoticness represents the uncertainty and the surge of the human soul. ${ }^{7}$

In the light of his writings, we can presuppose a clear link between the concept of the storm and anger: tempestas ... desaevit. ${ }^{8}$ Anger is the most dangerous of all tempers since it is not gradual, and it strikes mercilessly and imperturbably like the lightning and the thunderstorm. ${ }^{9}$ In this direct comparison, Seneca demonstrates the symbolic equivalence between anger and the visual representation of the storm, in view of its unmanageable intensity. The other complementary side of the storm metaphor signifies insecurity and the human wavering. Seneca, as the propagator of Stoic tranquility, identifies the uncertain mind with thousand waves: mille fluctus mentis incertae ${ }^{10}$ furthermore, he also explains that the ones who are inconsistent and likely to waver a lot do not focus on one path, and such people must face many "storms". ${ }^{11}$

The two complementary forms of the storm imagery are displayed at the same time in Seneca's Medea. Both the nurse and Medea herself refer to her fury, her unstable and angry state of mind with the various visual representations of the storm. The nurse, who worries about Medea's unpredictable forthcoming actions, compares the heroine's

3 See e.g. Rosenmeyer's note (1989: p. 97) regarding snake metaphors: "It is characteristic that in Euripides' version of the tale there is none of this."

4 Seneca uses these pictorial representations, albeit less often, in his other prose works as well, e.g. in Naturales quaestiones: on Winds (Book 5). In this passage Seneca creates a link between winds and greed. Winds, in themselves indifferent, are transformed to evil purposes by human vice. As Rosenmeyer (1989: p. 99) says: "It is hard to escape the impression that Seneca is, however cumbrously, saying something about the more than figurative identity of cosmic and human disturbances (...) - the juxtaposition creates its own presumption of affinity."

5 Unlike the Stoic sage, the actions and thoughts of a person who is overwhelmed by anger are characterized by fluctuations and inconstantia. On the issue of inconstantia in Seneca's characters, see Tietze (2007).

$6 \quad$ Braicovich (2017: p. 112).

7 Letica (2016: p. 51). The storm imagery at the beginning of the drama predominantly represent uncertainty, but as Medea's fluctuations culminate and her anger wins, the image of the storm embodies her wrath.

8 Sen. dial. 5,1,1: (...) dum tempestas prima desaeuit, ne remedia ipsa secum ferat.

9 Sen. dial. 5,1,4: Etiam si resistere contra adfectus suos non licet, at certe adfectibus ipsis licet stare: haec, non secus quam fulmina procellaeque et si qua alia inrevocabilia sunt quia non eunt sed cadunt, vim suam magis ac magis tendit.

10 Sen. dial. $9,11,10$.

11 Sen. dial. 9,9,3: non potest umquam tanta uarietas et iniquitas casuum ita depelli, ut non multum procellarum irruat magna armamenta pandentibus. 
emotional state to the waves, wondering where they will strike and where they will be broken. ${ }^{12}$ With the metaphor of turbulent water and waves, Seneca illustrates Medea's anger and vagueness in one powerful image. The representation of the wave is not only destructive, but it also expresses the insecurity, fluctuation and variability of the soul as the nurse wonders where this wave will be broken. Waves are, by their nature, unpredictable and free-flowing. Seneca, following Stoic ideals, finds anger similarly inconsistent and fluctuating. Later, Medea depicts her emotional state with the same characteristics, expressing her anger and uncertainty with a strong comparison: as the winds fight and the sea roars, so does her soul, breaking the whirlwind into two directions. ${ }^{13}$ Seneca also uses the imagery of the sea storm here as a direct comparison. The winds are angrily fighting (bella ... gerunt), and the expression of dubiumque fervet pelagus synthesizes the two key aspects of the metaphor: the sea is uncertainly murmurs in its anger. Medea is aware of the fluctuations of her emotions: her anger, her vindictiveness and her love. As the whirlwinds and other forces of nature are able to create chaos in the natural cycle of the world, the whirlwinds of the soul are naturally deviant forces in themselves and occasionally overcome rationality. According to Williams, Seneca's human's whirlwinds are "natural deviants", and occasionally human ratio is conquered by the excesses of these irregular but sometimes evitable forces. The scholar claims that the uncontrolled brutality of the whirlwind "offers an analogy for the human waywardness portrayed in the moralizing portions of the book." 14 The winds and storms has obvious symbolic interpretations and implications for self-control at human level. Thus, the whirlwind does not necessarily signify specific emotions but suggests that winds are, by their very nature, chaotic, and thus can reflect human nature. Metaphors illustrating the anger and the fluctuations of the soul with storm imagery are crucial to Seneca, actually indicate the deviant human nature globally, i.e. the personality of those who do not practice Stoic philosophy. ${ }^{15}$

In this regard, an all-inclusive storm analogy can be found in De Ira, where, Seneca explains the ultimate analogy of human emotions concerning the concept of the storm: just as the upper atmosphere is free from the disturbance of storms and whirlwinds, the ideal Stoic mind, which is sublime and wise, is free from deviance and emotions, such as anger, uncertainty and the turbulence of the soul. However, just like lightning strikes in the lower parts of the atmosphere, and there are clouds and storms, in the soul of the vile human being, there could be storms being accompanied by anger, revenge and pas-

12 Sen. Med. 390-392: haeret: minatur aestuat queritur gemit./ quo pondus animi verget? ubi ponet minas?/ ubi se iste fluctus franget? exundat furor.

13 Sen. Med. 939-944: anceps aestus incertam rapit;/ ut saeva rapidi bella cum venti gerunt,/ utrimque fluctus maria discordes agunt/ dubiumque fervet pelagus, haud aliter meum/ cor fluctuatur: ira pietatem fugat/ iramque pietas (...).

14 Williams (2005: p. 422).

15 According to Letica (2016: p. 58), Seneca "fashions the figure of the storm into the antithesis of the ideal Stoic mind." By relating the mind to the cosmos and atmosphere, Seneca carries out the traditional Stoic connection of the person to the universe. 
sion. ${ }^{16}$ This is what happens in the case of Medea: she is not able to prevent the passions in her soul from becoming actions; her ability to listen to her ratio weakens due to her emotions. She becomes emotionally isolated, with her inner tension being unbearable, and the destructive force of her passion overwhelms her. In the end, she commits the fatal act.

\section{Fire metaphor as Medea's anger}

The metaphor of the fire, like that of the sea storm, also serves to reveal the destructive nature of human anger and passion in Seneca's Medea. It is one of the strongest and most destructive elements of the nature, being similar to human anger: once we give ourselves to it, it is almost impossible for us to keep our social relations intact. According to Seneca, there is nothing advantageous in the destructive passion of anger, ${ }^{17}$ but on the contrary, all sorts of evil, fire and sword. ${ }^{18}$ In his De Constantia Sapientis, Seneca emphasizes the stability of the Stoic wisdom, which is defended by impenetrable walls from the fire, having no gap in them, being high, inaccessible, free of flame and brutality. ${ }^{19}$ In De Ira, he describes the appearance of the angry man with the metaphor of the fire: his eyes blinking in fire, his face turning towards it, and his wildness and unpredictability are similar to the nature of the fire. ${ }^{20}$

In the tragedy, it is also the metaphor of the heroine's rage and passion, a metaphor which is difficult to distinguish from its role in the mythology - which was at Seneca's disposal - as an integral part of it: the flaming chariot of the Sun, the boiling of Pelias, Aeetes' fire-breathing bull, the Argonauts whose deaths are linked with fire (Hercules, Nauplius, Ajax), the burning of the king, the princess and the palace. ${ }^{21}$ At the same time, the motif of the fire gains further aspects in Seneca's Medea with the explicit expressions of the heroine's anger and passion by the chorus, the nurse and the heroine herself. The chorus characterizes the self-blindness of the heroine's fury with this motif, its destructiveness and her incapacity of compromise: the chorus compares her determination to the fire, which cannot be restrained if it is intensified by revenge. ${ }^{22}$ It cannot be controlled with bridle once it has been manifested, in which case it is very difficult to

16 Sen. dial. 3,6,1: Nullum est argumentum magnitudinis certius quam nihil posse quo instigeris accidere. Pars superior mundi et ordinatior ac propinqua sideribus nec in nubem cogitur nec in tempestatem inpellitur nec versatur in turbinem; omni tumultu caret: inferiora fulminantur. Eodem modo sublimis animus, quietus semper et in statione tranquilla conlocatus, omnia infra se premens quibus ira contrahitur, modestus et venerabilis est et dispositus.

17 Contrary to what Aristotelians believe (Sen. dial. 3,9-12; 3,17,4; 3,17,7).

18 Sen. dial. 5,41,3: Nihil ergo habet in se utile taeter iste et hostilis adfectus, at omnia ex contrario mala, ferrum et ignes.

19 Sen. dial. 2,6,8: sapientem tuentur et a flamma et ab incursu tuta sunt, nullum introitum praebent, excelsa, inexpugnabilia, dis aequa.

20 Sen. dial. 3,1,4: flagrant ac micant oculi (...).

21 Pratt (1963: p. 214). Pratt claims that these cases are external and non-figurative, but obviously carry violence, conflict and destruction and are inseparable from the core meaning of fire in the drama.

22 Sen. Med. 591-593: caecus est ignis stimulatus ira/ nec regi curat patiturue frenos/ aut timet mortem. 
follow the advice of rationality, to deliberately invert the soul's sense of vengeance and to prevent the negative consequences of its possible offense. In other places, Seneca presents Medea's anger with the use of even stronger and more dangerous images than the devastating power of fire as the deceived and frustrated woman burns. ${ }^{23}$ The nurse describes Medea's anger in the following terms: she feeds her fury in the fire of her soul. ${ }^{24}$ The metaphor of the flame can be interpreted here as the "shadow" of the soul, which, upon the effects of anger and the resultant vengeance, glimmers first, slowly manifests itself, and then in its power irreversibly causes destruction. Seneca also describes her physical appearance with the metaphor of fire: her face is flaming as soon as she comes to know the wedding of Iason (flammata facies). ${ }^{25}$ Medea also uses this metaphor to display her wrath and vengeance when she calls Hecate to prepare herself for the feast of death and calls the flames to rampage and destroy everything. ${ }^{26}$

\section{Combination of storm and fire metaphors}

Seneca often combines the motifs of the storm and the fire to make a more expressive portrayal of anger both in his prose writings and in Medea. Anger is a monster like the fire, sea storm and darkness. In Quaestiones Naturales, following the Stoic traditions, he writes about fire and water as a whole. They guide the earth and its positive but also destructive sources. ${ }^{27}$ In $\mathrm{De}$ Ira, he also uses the metaphor of fire and sea storm as anger metaphors several times: the angry man's eyes burn in fire, anger changes the calm sea to stormy, only destruction and darkness remain behind..$^{28}$ According to Seneca, the Stoic wise mind is like a rock that is impenetrable in the case of fire, and it preserves its strength and shape; just as some of the rocky cliffs which break the foams, but they do not show any evidence of the anger of the sea that has been attacking it for so long (non possunt igne consumi ... scopuli mare frangunt).${ }^{29}$ The same is true of the Stoic soul: it is strong and unbreakable in the case of every blow. Seneca illustrates the dangerous nature of human passions by showing the destructive powers of the fire and the sea, which must be prevented.

In the tragedy, in response of the nurse's warning, the heroine characterizes herself with the metaphors of these two elements: she wants the nurse to see the fire and lightning in her, that is, the overwhelming power of the fire and storm (uides ignes et deos et

23 Sen. Med. 579-582: Nulla uis flammae tumidiue uenti/ tanta, nec teli metuenda torti/ quanta cum coniunx uiduata taedis/ ardet et odit.

24 Sen. Med. 671-672: immane quantum augescit et semet dolor/ accendit ipse uimque praeteritam integrat.

25 Sen. Med. 387.

26 Sen. Med. 577-578: uocetur Hecate. sacra letifica appara:/ statuantur arae, flamma iam tectis sonet.

27 Sen. nat. 3,28,7. Rosenmeyer (1989: p. 128). The Stoics differentiated between 'productive fire', the fundamental element; and 'destructive fire', "the fire that stands for the negative volatility of the world, and that periodically erupts in an act of total conflagration."

28 Sen. dial. 4,35,5;3,12,4;5;27,2.

29 Sen. dial. 2,3,5. 
fulmina). ${ }^{30}$ The interconnection of the two metaphors is reflected in the words of Medea when she characterizes her anger: the swirling Pontus and the fire that is blowing in the wind are not as powerful and destructive as the anger of her soul. ${ }^{31}$ Mare ... fervebit ... procellosum mare ... vis ignium: the metaphor-pair repeat, interweave and reinforce each other's destructive meaning. The chorus also uses this metaphor-pair when defining Medea's anger: there is no such force in the fire or the sea storm as in the blazing anger of the heroine.$^{32}$ As a result of her wrath, the twin coast Corinthus burns down, and the two seas clash. ${ }^{33}$

At the end of the drama, we can witness the destructive and complementary aspects of these two elements: the water does not extinguish the fire but increases its flame; and their destructive powers unite, reaching their peaks (alit unda flammas) ${ }^{34}$ Medea's revenge is done, and her anger metaphors although carrying many contradictions, interweave as combined expressions of the heroine's emotional state: Medea is a flaming storm of passion.

\section{Snake metaphor as Medea's wrath and revenge}

The other central image of the drama is the snake, which is interpreted since the beginning of the drama as the metaphor of Medea's wrath and her revenge which arises from her anger. As claimed by Nussbaum, snakes are emblems of Medea's love and the anger of her love, and are undoubted symbols of sexual pleasure as well. Seneca allows the spectator to see the "price" of eros, as the "snaking flame penetrates to her inmost marrow." 35 In contrast, I highlight the anger-expressing aspect of these metaphors, as I believe they have a greater dominance in this drama. Snakes have a wide range of symbols in Latin literature. The works often emphasize their chthonic nature, their poisonousness, wildness and unpredictability. ${ }^{36}$ Seneca uses the threatening, silent, unpredictable and deadly image of the animal, the hidden nature of its destructiveness. The movements of snakes are indirect, wavy and tortuous as they come out of their hiding place, find their victims, touch them once and already impregnate it with poison.

In his prose works, Seneca also pays attention to the snake motif. He combines the intensity and process of anger with the nature of the snakes: it first appears latent, then

30 Sen. Med. 166-167. Németh (2017: p. 67). Medea's wrath, as Helios' granddaughter, traverses the universe in Zeus' fiery lightning (ignes et fulmina), Medea's mindless rage shapes her own world. The character is thus nothing more than the incarnate anger itself, which is the lightning rage of destruction without proper discernment.

31 Sen. Med. 408-414.

32 Sen. Med. 579-588: Nulla vis flammae tumidive venti tanta/ nec teli metuenda torti,/ quanta cum coniunx viduata taedis/ ardet et odit.

33 Sen. Med. 35-36: gemino Corinthos litori opponens moras/ cremata flammis maria committat duo.

34 Sen. Med. 889-890.

35 Nussbaum (2009: p. 463).

36 See Knox (1950). Knox in his article The Serpent and the Flame collects many examples of snake imagery. For other references to snakes see also Vígh (2019: pp. 183-189). 
manifests and afflicts quickly. Its first "hits" are wild and cruel, but then it gets exhausted as when the snake bites again its fangs are harmless. ${ }^{37}$ In light of this, anger quickly manifests itself and reaches its maximum intensity, but it quickly loses its strength, which is why it is inconsistent, unable to compromise, exceeding the required limit or stopping before time. The snake's bite also works in a similar way. Its first bites are deadly, but then they are harmless. In De Clementia, he uses the snake metaphor to impersonate the evil man. The tiny snakes remain unnoticed, we cannot perceive or find them, but when one suddenly becomes a monster, their destructive power manifests, and they cannot be stopped: founts are infected by its saliva, its breath poisons and causes destruction. ${ }^{38}$

In the tragedy, they first appear in the hair of the furies, foreshadowing the heroine's revenge by their writhing bodies. ${ }^{39}$ The snake motif - especially in the hair of the deities of revenge, but also in the form of a snake whip - is the attribute of furies as illustrating revenge and destructiveness. ${ }^{40}$ The chorus also emphasizes the lethal character of the serpent, according to which even Idmon - although he knew his fate - could not fight against the serpent in Libya. ${ }^{41}$ The snake metaphor appears again in the fourth act of the nurse's frightened monologue when she talks about Medea's magic speech. Medea calls all the snakes of earth and sky. Rosenmeyer claims that the witchcraft scene is "the totalization of the Stoic insight that the world, qua corporeal, is also animal, and an aggregate of animality." 42 Medea's spell is an implementation of her wrath to control the cosmos. The snakes, dragons are cosmic beasts representing the hellish forces released into the world by Medea for her horrible aims. The snakes of earth and sky, which ominously come from their hiding places to the words of the heroine, are aware of their power and threaten with their tongues. ${ }^{43}$ In this sense, they are the metaphor of death, destructiveness and the representation of evil beings in the heroine's soul. After that, we meet snakes in the heroine's monologue when she calls the Snake, the northern constellation of the sky between the two Bears, after Pytho, Hydra, and Colchis' serpent to serve her vengeance by their deadly poisons. ${ }^{44}$ Then she calls Phoibe, to whom she makes a wreath from the victims of nine serpents and offers her Typhocus' body. ${ }^{45}$ In her monologue, she gathers all species of snakes to fulfill her vengeance, ${ }^{46}$ and she draws poison from

37 Sen. dial. 3,17,6: Primi eius ictus acres sunt; sic serpentium venena a cubili erepentium nocent, innoxii dentes sunt, cum illos frequens morsus exhausit.

38 Sen. clem.1,25,4: Serpentes parvolae fallunt nec publice conquiruntur; ubi aliqua solitam mensuram transit et in monstrum excrevit.

39 Sen. Med. 14-15: crinem solutis squalidae serpentibus/ atram cruentis manibus amplexae facem.

40 However, this is not Seneca's originality only, as its mythological role was available for the playwright. For literary examples of furies' snake motifs see Boyle (2014: p. 112).

41 Sen. Med. 652-653: Idmonem, quamvis bene fata nosset,/ condidit serpens Libycis harenis.

42 Rosenmeyer (1989: p. 97).

43 Sen. Med. 686-688: hic saeva serpens corpus immensum trahit/ trifidamque linguam exertat et quaerit quibus/ mortifera veniat...

44 Sen. Med. 694-704.

45 Sen. Med. 771-774: Tibi haec cruenta serta texuntur manu,/ nouena quae serpens ligat,/ tibi haec Typhoeus membra quae discors tulit,/ qui regna concussit Iouis.

46 Sen. Med. 705-706: Postquam euocauit omne serpentum genus/ congerit in unum frugis infaustae mala. 
their body that keeps the hidden core of fire, and this fiery poison will be Creusa's destiny (urat serpens flamma medullas).$^{47}$ After the spell, the snake motif appears at the end of the drama when a group of furies emerge and the figure of the heroine's brother calls for revenge, and his whip writhes as a giant snake (ingens anguis excusso sonat). ${ }^{48}$ At the end of the work we also encounter the symbol of the animal: she ascends to the sky on her flying chariot with winged serpents, which animals voluntarily turn their spiky necks under her yoke. ${ }^{49}$

The intentional connection of the snake and fire motifs can be also observed to represent anger both in Seneca's prose works and in Medea, as the snake and the dragon metaphors carry the motive of fire. In De Ira, he speaks about the appearance of the angry man, that his body becomes ugly also with his soul; and he compares wrath to underworld monsters surrounded by snakes and fiery flames (succincta serpentibus et igneo flatu). ${ }^{50}$ In Medea, the invocation of deities of vengeance carries the merging of these two metaphors: both are the attributes of the furies, their hair are full of snakes, and they have flaming torches in their bloody hands. ${ }^{51}$ When Medea calls Hecate, the two anger metaphors are combined: a snakelike flame (Medea's anger and vengeance) burns Creusa, and she finds a terrible death (urat serpens flamma medullas). ${ }^{52}$

The snake and fire metaphors express, anticipate and amplify the sinister destiny of the drama, the revenge of the heroine, which is unstoppable, invisible and deadly as the fire and poisonous as the snake bite.

\section{Conclusion}

The genre of the tragedy cannot provide a sufficiently broad framework for a detailed presentation of the "complete" meaning of these pictorial representations, but in comparison with Seneca's prose, we can still gain a greater insight into the nature of the "Senecan metaphors", thus we can examine it more thoroughly.

Seneca's metaphors are used for cognitive purposes, consciously transferring his Stoic philosophy in relation to human passions. The Stoic philosopher creates a sort of "inner genuineness and dynamics" of the drama by means of pictorial representations and metaphors taken from nature. The destructive forces of nature signify Medea's failure to listen to rationality, thus these are metaphors of chaos and moral degradation. Just as the invincible fire, the raging sea storm and the indomitable, aggressive snake carry destruction, Medea's wrath is deadly, uncontrollable, devastating and poisonous. By analysing these metaphors altogether, we get a clear explanation for their purposes. In

47 Sen. Med. 818.

48 Sen. Med. 961-962.

49 Sen. Med.1023-1024: squamosa gemini colla serpentes iugo/ summissa praebent.

50 Sen. dial. 4,35,5.

51 Sen. Med. 14-15: crinem solutis squalidae serpentibus/ atram cruentis manibus amplexae facem.

52 Sen. Med. 818-819. 
the tragedy Seneca creates subversely a counterworld to the world of Stoic virtue, and metaphors are applied not only to the different manifestations of human nature as direct comparisons, but also to express Stoic ideals: if we do not live according to the Stoic philosophy and in harmony with nature, the balance of the soul might be shaken, and emotions might take control over our rational decision-making ability. By relating the mind to the cosmos and atmosphere, Seneca carries out the traditional Stoic connection of the person to the universe, projecting personal emotion into a cosmic frame.

\section{Bibliography}

\section{Primary Sources}

Cooper, J. M., \& Procopé, J. F. (Eds.). (1995). Seneca: Moral and Political Essays. Cambridge: Cambridge University Press.

Corcoran, T. H. (Transl.). (1989). Seneca: Naturales Quaestiones, Books 1-3. Cambridge: Harvard University Press.

Fitch, J. G. (Ed.). (2018). Seneca. Tragedies, Vol. I: Hercules. Trojan Women. Phoenician Women. Medea. Phaedra. Cambridge: Harvard University Press.

Reynolds, L. D. (Ed.). (1965). Ad Lucilium Epistulae Morales, Books 14-20. Oxford: Oxford University Press.

Stevenson, D., \& Stewart, A. (Transl.). (2015). Dialogues by Seneca. Los Angeles: Enhanced Media Publishing.

\section{Secondary Sources}

Bartsch, S. (2009). Senecan metaphor and Stoic self-instruction. In Idem, \& D. Wray (Eds.), Seneca and the Self (Vol. 101; pp.188-221). Cambridge: Cambridge University Press.

Boyle, A. J. (2014). Medea, edited with Introduction, Translation, and Commentary. Oxford: Oxford University Press.

Braicovich, R. S. (2017). Seneca's Medea and De ira: Justice and Revenge. Journal of Ancient Philosophy, 11, 106-119.

Inwood, B. (2008). Reading Seneca: Stoic philosophy at Rome. Oxford: Oxford University Press.

Knox, B. M. W. (1950). The Serpent and the Flame: The Imagery of the Second Book of the Aeneid. The American Journal of Philology, 71, 379-400.

Letica, A. (2016). Storm Imagery in Senecan Poetry and Prose. Discentes, 2, 50-60.

Németh, A. (2017). Metadráma Seneca Medeájában. Ókor, 2, 65-70.

Nussbaum, M. C. (2009). Serpents in the Soul: A Reading of Seneca's Medea. In Idem, The Therapy of Desire: Theory and Practice in Hellenistic Ethics (pp. 439-483). Princeton: Princeton University Press.

Pratt, N. T. (1963). Major Systems of Figurative Language in Senecan Melodrama. Transactions and Proceedings of the American Philological Association, 94, 199-234. 
Rosenmeyer, T. G. (1989). Senecan Drama and Stoic Cosmology. Berkeley: University of California Press.

Segal, C. (2008). Boundary Violation and Landscape of the Self in Senecan Tragedy. In J. G. Fitch (Ed.), Seneca (Oxford Readings in Classical Studies; pp. 136-156). Oxford: Oxford University Press.

Setaioli, A. (2007). Seneca and the divine: Stoic tradition and personal developments. International Journal of the Classical Tradition, 13, 333-368.

Tietze, V. (2007). The Psychology of Uncertainty in Senecan Tragedy. Illinois Classical Studies, 12, 135-141.

Vígh, É. (2019). Állatszimbólumtár. Budapest: Balassi kiadó.

Williams, G. (2005). Seneca on Winds: The Art of Anemology in Natural Questions 5. American Journal of Philology, 126, 417-450.

Katalin Bán / ban.katalin90@gmail.com

Doctoral School of Literature

University of Szeged, Faculty of Arts

Egyetem utca 2, 6722 Szeged, Hungary 
